\title{
Resumen / Memoria y experimentación en el cine argentino contemporáneo
}

Este artículo analiza dos películas argentinas que son de las más innovadoras de los últimos años, en cuanto a estética y también a su potencial para abrir nuevos espacios de debate cultural y político. En Los rubios (Albertina Carri, 2003) y Potestad (Luis Cesar D'Angiolillo, 2003), la subversión deliberada de procesos convencionales de la cinematografía es fundamental en su examen de la crisis de memoria, identidad y representación en la Argentina de hoy. El artículo recurre a distintos teorías cinematográficos y culturales para indagar sobre la compleja relación que trazan estas películas entre el cine y la política, así como su aporte importante al debate actual sobre la memoria.

\section{Palabras clave}

Acción política - desvío - dictadura - dispositivos - estructura - género - genocidio - imágenes - reacción sociedad.

\section{Summary /Memory and experimentation in the contemporany argentine cinema}

This article analyses two Argentine films which are among the most innovative of recent years, both in aesthetic terms and in their potential to open up new spaces for cultural and political debate. In Los rubios (Albertina Carri, 2003) and Potestad (Luis César D'Angiolillo, 2003), the deliberate subversion of conventional cinematographic processes is key to their exploration of the crisis of memory, identity and representation in contemporary Argentina. The article draws on a variety of cultural and film theories in its investigation of the complex relationship traced by these films between cinema and politics, and to assess the importance of the contribution they make to contemporary debates on memory.

\section{Key words}

Deviation - dispositive - dictatorship - genocide - genre - image - political action - reaction - society structure.

\section{Resumo / Memória e experimentação no cinema argentino contemporáneo}

Este artigo analisa dois filmes argentinos que são dos mais inovadores dos últimos anos na estética e também no potencial para abrir novos espaços de debate cultural e político. Em Los rubios (Albertina Carri,2003) e Potestad (Luis César D'Angiolillo, 2003), a subversiva deliberada de processos convencionais da cinematografia é fundamental no exame da crises de memória, identidade e representação da Argentina de hoje. $\mathrm{O}$ artigo percorre as diferentes teorias cinematográficas e culturais para indagar sobre a complexa relação que estes filmes traçam entre o cinema e a politica.

\section{Palavras chave}

Ação política - desvío - dispositivos - ditadura -estrutura - gênero - genocídio - imagens - reacção sociedade.

\footnotetext{
* Joanna Page. Doctora en Literatura . Universidad de Cambridge. Profesora full time e investigadora permanente del Centro de Estudios Latinoamericanos de la Universidad de Cambridge. Miembro del Comité Editorial publicaciones Centro de Estudios en Diseño y Comunicación. Facultad de Diseño y Comunicación. Universidad de Palermo.infocedyc@palermo.edu
} 
Veinte años de palabras y de imágenes con que se ha intentado reconstruir la experiencia de la dictadura en Argentina, lejos de saturar la necesidad por tal reconstrucción, han revelado más frecuentemente lo que ha quedado sin representar o lo que está más allá de la representación. A esta sensibilidad se le puede atribuir el éxito de la última película de Marcelo Piñeyro, Kamchatka (2002), la primera en emprender un examen sostenido de los eventos de la dictadura desde la perspectiva limitada y conmovedora de un niño de diez años. La película fue acogida con entusiasmo por un público de treintañeros que también había experimentado el régimen militar de lejos, y cuyos recuerdos eran de conversaciones susurradas entre adultos, y pequeñas y misteriosas privaciones de libertad. La experiencia de la dictadura también sigue proporcionando material para las propuestas más experimentales del cine independiente. En este artículo examinaré dos películas contemporáneas que marcan un cambio de dirección importante dentro de los debates políticos y culturales acerca de la memoria en la Argentina posdictadura: Los rubios, de Albertina Carri, y Potestad, de Luis César D'Angiolillo, ambas estrenadas en 2003. A primera vista, son producciones que parecen radicalmente distintas. Los rubios fue recibida como el hallazgo del año por críticos argentinos y extranjeros, mientras que Potestad, aunque viajó por varios festivales internacionales, ha pasado casi sin ser percibida entre los críticos nacionales. Las películas se relacionan entre sí por cierta ubicación del espectador que, a su vez, se relaciona con cierta reconsideración de la memoria posdictadura. La subversión deliberada de procesos convencionales de la cinematografía es fundamental en su examen de la crisis de memoria, identidad y representación. Como películas, mantienen sólo una relación muy indirecta con el ímpetu testimonial que ha regido muchas películas de la época posdictadura, entre ellas La historia oficial, Un muro de silencio y Garage Olimpo. En cambio, montan nuevos escenarios y marcan virajes muy importantes dentro de los debates sobre la memoria y la representación. Son a la vez muy contemporáneas y contraculturales.

Los rubios está inspirada en la búsqueda de la directora por descubrir más sobre sus padres, Roberto Carri y Ana María Caruso, militantes de izquierda que desaparecieron en el 1977, cuando Albertina tenía sólo tres años. Los críticos han tratado de resumir la complejidad de la película con términos como "metadocumental", "una road movie sobre el cine" (García, L. 2003), e incluso "un reality show sobre la memoria" (Julián Gorodischer, cit. Moreno 2003). Pero sería más exacto definir la película como un documental reflexivo o performativo, según la definición que nos proporciona Stella Bruzzi, para quien el uso de la actuación dentro de un documental "llama la atención a la imposibilidad de representación documental auténtica", siendo "un recurso alienador, distanciador, que no estimula activamente ni la identificación ni una reacción sencilla al contenido de la película" (2000: 153-54). Que Carri haya optado por este modo de hacer cine es sorprendente: tanto la urgencia política como el peso autobiográfico parecerían exigir un marco realista. Pero la realidad histórica, como el espectador descubre rápidamente, no es el enfoque de este documental. Por el contrario, indaga las ficciones que crea la memoria con el fin de llenar las fisuras de la historia. Los rubios saca a la luz la complicidad del cine que tiende a proveer ilusiones de coherencia, clausura e incluso de experiencia, suturando al espectador en una narrativa que produce una simple identificación emotiva que tiene como resultado final la complacencia política. Por medio de una serie de recursos distanciadores, la película perturba la identificación, se niega a permitir la catarsis al espectador y llora simplemente la imposibilidad de llorar, la ausencia de la historia y la experiencia, y el efecto de estas ausencias sobre la identidad y la conciencia política en el presente.

Este proceso de perturbación es obvio a primera vista en la construcción narrativa del film. La historia principal, la de la investigación de Albertina sobre las circunstancias de la desaparición de sus padres, se encuentra continuamente descarrilada por otra narrativa, que es el making of de Los rubios. La narrativa principal, que contiene entrevistas con parientes, amigos y vecinos, e incluye una visita al centro de detención donde sus padres estuvieron encerrados, se filma, por lo general, en color y en película de 16 milímetros. Como contraste, las escenas que muestran ensayos y las actividades del equipo de rodaje están mayormente en video, y en blanco y negro. Sin embargo, estas distinciones no se respetan a lo largo del film, y esta transgresión de la línea divisoria entre las dos narrativas sirve para demostrar la contaminación de narrativa con metanarrativa, un tema de significado particular en la investigación que hace el film sobre la memoria. Estos dos hilos narrativos se suspenden de vez en cuando, dándole lugar a otro, filmado en animación stop-motion, en que pequeños muñecos Playmobil participan de varias actividades que giran alrededor de una casa y un jardín: disfrutan de un asado, juegan al voley, bailan y nadan en la pileta. Estas escenas ofrecen un comentario sobre las otras narrativas; generan con frecuencia un efecto cómico y así quitan deliberadamente la autoridad y la credibilidad del film como documental.

La investigación de Albertina se centra en tres lugares diferentes, cada uno de los cuales adquiere un valor simbólico en el contexto del film. La acción se traslada entre el barrio donde vivía cuando secuestraron a sus padres, que es, dentro de la película, el lugar de la historia y de la realidad sin procesar; el campo, asociado con la niñez y la fantasía; y la ciudad, el lugar de la adultez y la reflexión, representadas por la soledad del estudio y los viajes, muchas veces silenciosos, del equipo de rodaje por las avenidas y las autopistas de Buenos Aires. Las entrevistas filmadas en el barrio parecen ser las escenas que menos se han editado, y representan casi en tiempo real la duración de los recuerdos contados y las divagaciones de los entrevistados. Como contraste, muchas de las escenas que se filmaron en el campo, al que Albertina y sus 
hermanas se mudaron después de la desaparición de sus padres, son tomas de pura experimentación cinematográfica. Presentan un catálogo de posibles movimientos de cámara y efectos de montaje: jump cuts (cortes con un salto mínimo de ángulo) de alternación muy rápida, recorridas panorámicas de trescientos sesenta grados, y travellings que captan una figura y están editados juntos para crear la ilusión de dobles múltiples. Estas técnicas exponen las herramientas del trabajo de cine, insistiendo en la materialidad de la película, y de esta manera estas escenas - que no tienen ningún significado claro en términos narrativos- inhiben una entrada emocional en la historia. Generan un efecto parecido las secuencias que captan el equipo de rodaje: éstas se componen muchas veces de una serie de fotogramas, que cortan literalmente la progresión de la narrativa y sugieren una forma de estancamiento, un lugar de reflexión fuera del tiempo narrativo del film.

La identificación del espectador con la protagonista se torna todavía más problemática a causa de recursos duplicantes y aun triplicantes. En este sentido, LoS rubios deja atrás muchos otros documentales performativos y introduce otro espejo para deformar y refractar la relación entre director y actor. La intervención del cineasta en un documental siempre pone de manifiesto el hecho de que la representación documental no sea más que una ficción; en estos casos, el director no está presente como testigo objetivo, sino como otro sujeto que interactúa con los sujetos del film. En Los rubios, la intervención de Carri es doble: como director y también como protagonista de su propio film; además, la presencia de Carri está complementada con la de otra actriz, Analía Couceyro. Analía se presenta cerca del comienzo de la película y explica claramente, frente a la cámara, que va a hacer el papel de Albertina. Más tarde vemos a Carri explicándole cómo representar su personaje, y nunca logramos olvidar que Analía está representando un papel. Por lo menos tres Albertinas se revelan en el texto del film: la verdadera Albertina, el sujeto del film que inicia una búsqueda para descubrir más sobre sus padres; Albertina la directora, que aparece como ella misma, filmando y editando los resultados de esa investigación; y Analía-Albertina, la actriz.

Tales repeticiones y refracciones hacen que estemos constantemente conscientes de la naturaleza mediatizada y performativa del material del film. En una de las pocas escenas en que Analía-Albertina medita de modo directo sobre su pérdida, el uso de una técnica de distanciamiento hace que se pierda todo efecto de patetismo. Escuchamos a Analía que enumera las cosas que (como Albertina) odia; las últimas en la lista son las velitas de cumpleaños, porque de chica siempre pedía tres deseos: "que vuelva mamá, y que vuelva papá, y que vuelvan pronto. En realidad es un solo deseo, pero siempre lo estructuré en tres partes para que tuviera más fuerza". Pero la escena se filma en dos tomas, y en la primera una segunda cámara permanece fijada en Carri, que filma a Analía y la interrumpe, de vez en cuando, para explicarle con más precisión cómo quiere que recite las frases. Cuando pasamos a la segunda toma, en la que nuestra perspectiva vuelve a ser la de la cámara de la directora, la repetición de las frases y nuestra conciencia de estar mirando a través de los ojos de la directora se combinan para quitarle valor a lo que se está contando. Simultáneamente creemos y descreemos en la "verdad" de estos recuerdos, y para el espectador, la experiencia de verse enfrentado así a los procesos de identificación y el desmentido resulta incómoda. Por lo general, escenas de emotividad brillan por su ausencia en el film, y cuando las hay, no se representan con realismo. Incluso la escena en que Analía, sola en el bosque, grita sin pronunciar palabras, parece forzada y es la mera representación de dolor. Una voz en off, en el tono tranquilo y frío de reflexión, explica que le había costado entender la decisión de su madre de no huir del país cuando todavía era posible. Como espectadores, nunca nos está permitido olvidar el hecho de que Analía esté haciendo un papel. Cuando la búsqueda de información sobre los padres de Albertina las lleva a ambas chicas al Centro de Antropología Forense, se hace un análisis de sangre de las dos, primero Analía y después, Albertina: aunque la cámara debe registrar el pinchar del dedo de Analía (porque hace el papel de la hija de los desaparecidos), es obvio que sólo la muestra de sangre de la auténtica Albertina podría tener relevancia en términos biológicos. En esta escena se ve codificada la deconstrucción del film de conceptos de la autenticidad y la transparencia en relación a la representación.

Al igual que la interpretación de Analía está desacreditada por la intrusión de Albertina y las cámaras, la proyección del material "verdadero" del film se encuentra continuamente perturbado. Con muy pocas excepciones, todo el material que representa o reflexiona sobre el pasado lo vemos en la presencia persistente del equipo de rodaje y las cámaras. Nuestro acceso a muchas de las entrevistas se limita a escenas en que Analía, en primer plano, hace anotaciones en una laptop mientras pasa los entrevistas, grabadas en video, en un televisor ubicado permanentemente en un segundo plano. Estas escenas, que ponen énfasis en la materialidad de la película como producción, recuerdan escenas parecidas entretejidas en Chelovek s kinoapparatom/El hombre de la cámara (Dziga Vertov: 1929), aunque en este caso, por supuesto, el corte físico de celuloide se cambia por el clic de un mouse. Raramente se nos ofrece una toma directa y de frente de los entrevistados que, según convención cinematográfica, le imputaría verdad al testimonio. En cambio, lo que pasa por historia en este film es muchas veces parcial, fragmentado y desplazado, provisorio y de segunda mano. El desarrollo de la investigación de Albertina no se filma en vivo ni se recrea para las cámaras: se narra siempre en un estilo indirecto. Analía redibuja para la cámara un plano de las celdas, que le había mostrado Albertina a ella, y que le había dibujado a Carri una sobreviviente del centro de detención donde estaban sus padres. El dibujo resultante, que nos presenta Analía como "mi recuerdo de lo que ella 
dibujó en su recuerdo", es una representación a tres pasos de la realidad y una serie de casillas sin sentido que no nos cuenta nada de las celdas ni de la experiencia de vivir en ellas.

El film de Carri revela siempre la fragilidad de la memoria, que es falsa, vulnerable, porosa a la ideología, la nostalgia y el deseo, y cargada de la memoria oficial y los recuerdos de otros. Con todo paso que Albertina cree que la acerca más a la verdad, parece terminar más lejos de ella, sin poder distinguir sus propios recuerdos de los de sus hermanas: "lo único que tengo es mi recuerdo difuso, contaminado por todas estas versiones". De sus hermanas, Paula no quiere hablar frente a cámara; "Andrea dice que sí, quiere hacer la entrevista, pero todo lo interesante lo dice cuando apago la cámara". La familia recuerda "de una manera en que mamá y papá se convierten en dos seres excepcionales, lindos, inteligentes"; los recuerdos de los amigos de sus padres se estructuran de tal manera que "todo se convierte en un análisis político". Analía escribe:

Exponer a la memoria en su propio mecanismo.

Al omitir, recuerda. La memoria, como toda narrativa, se construye tanto sobre las lagunas y las ausencias como sobre la realidad histórica. Existe en Los rubios una ausencia que presenta un obstáculo insuperable a la represen-tación. Carri afirma que el hecho de que la película no revele nada de ninguna importancia sobre sus padres representa una negativa intencional a satisfacer las expectativas del espectador. Lo dice así: "Quería impedir que los diversos elementos como los testimonios, las fotos y las cartas dejen esa sensación tranquilizadora, ese ya está, conozco a Roberto y a Ana María y me voy a mi casa. Lo que yo planteo es precisamente que no los vamos a conocer, que no hay reconstrucción posible. Son inaprehensibles porque no están." (Moreno: 2003)

La intención fundamental de Carri no fue, afirma ella, la de contar la historia de su familia, sino ofrecer una perspectiva alternativa sobre el período de la dictadura; en ésto radica lo innovador de Los rubios.

Nunca me sentí representada por las voces interiores. Me parece que se ha tocado el tema de forma historicista o con demasiada vehemencia. Mi sensación es que nadie ha metido la mano en ese agujero negro que es la ausencia. Por lo general, las películas que han hecho sobre el tema surgen desde lo público (los desaparecidos, los jóvenes de la generación de los '70, la lucha, etcétera) para llegar a veces a una cosa íntima o más privada como el relato de una abuela o una madre. Yo quise hacer el camino opuesto. (García, L.: 2003)

Los rubios presenta la ausencia y la pérdida como experiencias irreducibles que no pueden, y no deben, aliviarse por el proceso de hacer un film; tampoco son experiencias que se puedan generar a través de la identificación cinematográfica para el provecho del espectador que busque una experiencia catártica o algún tipo de clausura ilusoria a un pasado difícil. La negación del film a contar una historia es un elemento esencial de su resistencia a lo que Carri define como "la memoria del supermercado". En su trabajo sobre las distintas formas del cine documental, Bill Nichols sugiere que el conocimiento conferido al espectador es "una fuente del placer que dista mucho de la inocencia" (1991:31). A diferencia de otros documentales más convencionales, el de Carri se niega a satisfacer en el espectador esa "sensación de la plenitud o la autosuficiencia" que identifica Nichols.

Si Carri nos mantiene distanciados de su historia, tampoco reserva un lugar de conocimiento para sí misma. En el contexto del Holocausto, Dominick LaCapra nos recuerda que "no hay acceso inmediato ni completo a la experiencia en sí aún para el testigo original, mucho menos para el testigo secundario y el historiador". Los rubios no intenta recrear la experiencia de pérdida para el espectador, precisamente porque para Albertina también queda inaccesible. De las entrevistas con parientes y amigos de sus padres, Albertina sólo descubre que su madre hizo un buen estofado y que su padre jugaba al voley en el jardín. El film no investiga las actividades de los padres, políticas o de otro tipo, de una manera que le diera cuerpo a su existencia. La búsqueda de identidad sólo arroja una miscelánea de accesorios superfluos, como la peluca rubia que Analía empieza a ponerse mientras trata de descubrir más sobre los padres de Albertina, que para muchos eran "los rubios". Hasta el título del film está plagado de contradicciones: si los padres de Albertina eran o no eran rubios es objeto de polémica entre los entrevistados. Como apunta Diego Lerer (2003), "Los rubios" connota simplemente la diferencia: "los rubios son los otros (los Carri, los militantes, los que no están, los desaparecidos, los que emigraron, los ausentes)"; dada la vehemencia con que la tía de Albertina insiste en que nadie en la familia era rubio, "los rubios" se vuelve un significante vacío que denota sólo los caprichos de la memoria. Además de evocar las operaciones ficcionalizadoras de la memoria, el título también recuerda las profundas divisiones políticas que caracterizaba la sociedad argentina de los años setenta, desde el discurso público del régimen militar hasta las denuncias autoproteccionadoras de los vecinos.

La memoria en Los rubios tiene que sortear la peligrosa red de la complicidad y del miedo que todavía parece existir en la Argentina contemporánea. AnalíaAlbertina nos dice que, en cierto círculos, pronunciar su apellido "todavía implica miradas extrañas, una mezcla de desconcierto y piedad". Los vecinos entrevistados no están dispuestos a expresar nada que se pueda interpretar como un comentario político. La primera señora se niega a hablar de la circunstancias de la desaparición de los padres, insistiendo en que lleva una vida "tranquila ... no tengo drama con nadie [...] jamás me han molestado por nada". La segunda, sin el más mínimo reparo, describe cómo los soldados entraron en la casa de ella por error, y cómo pudo indicarles cuál era la casa de los Carri: "para mí, fue una satisfacción", explica ella, porque con la desa- 
parición de estos vecinos volvió la tranquilidad al barrio. Los miembros del equipo de rodaje admiten estar nerviosos cuando les toca filmar dentro de la comisaría, y guardan sus ejemplares de Nunca más con sumo cuidado. Si existe un metadiscurso en Los rubios, es la voz en off que corresponde al diario de Albertina, pero ésta relata sólo lo que no se puede decir, registrando experiencias de fracaso, frustración y prohibición. Frente a los adornos de algunos amigos y la negativa rotunda de otros de hablar sobre el tema, Albertina-Analía dice "Me gustaría filmar a mi sobrino de seis años diciendo que cuando sepa quienes mataron a los papás de mi mamá, va a ir a matarlos. Pero mi hermana no me deja". La película muestra hasta qué punto el miedo y una falta de solidaridad inhiben la tarea urgente de reconstruir la identidad en la Argentina de la época posdictadura, ya que un elemento importante de esta tarea es, como lo expresa Carri en el film, "construirse con la mirada del otro".

Los rubios no es una película pesimista, e incluso trabaja ideas de restauración en la forma de una nueva solidaridad y una nueva familia, que está representada por el equipo de rodaje. Esto se ve claramente en la última secuencia del film, mientras se aleja el equipo de la cámara por un camino en el campo, muchos de ellos portando pelucas rubias. Sin embargo, queda claro que ésta es una generación huérfana, desprovista del protagonismo y de la identidad histórica. Carri toca un tema que está comenzando a salir a la luz en reflexiones actuales sobre la dictadura, que es la brecha generacional que divide a los que experimentaron el régimen militar en carne propia de los que se criaron después. Como dice Analía en el film: "Vivo en un país lleno de fisuras. Lo que fue el centro clandestino donde mis padres permanecieron secuestrados hoy es una comisaría. La generación de mis padres, los que sobrevivieron una época terrible, reclaman ser protagonistas de una historia que no les pertenece. Los que vinieron después, como Paula L., o mis hermanas, quedaron en el medio, heridos, construyendo sus vidas desde imágenes insoportables."

Carri misma pertenece a esta segunda generación, pero es más joven todavía, demasiado joven para experimentar la pérdida, pero condenada a criarse con esa ausencia como condición de la vida cotidiana. A las víctimas de la dictadura se les borraron la identidad y la posibilidad de participación histórica. Esta nueva generación tampoco logra obtener acceso a esa participación, pero por otra razón. Experimentan la historia siempre distanciados de la realidad, y por eso viven en una época cínica en que, como dice la película, "la mayoría de las respuestas se han perdido en la bruma de la memoria". El análisis de Marianne Hirsch del fenómeno de la posmemoria tiene mucho que ver con la evocación de la experiencia de segunda generación en Los rubios. La posmemoria se refiere a "la relación de hijos de sobrevivientes de trauma cultural o colectivo a las experiencias de sus padres, experiencias que "recuerdan" sólo como las historias y las imágenes con las cuales se criaron, pero que son tan potentes, $\tan$ monumentales, que constituyen recuerdos por derecho propio" (1999: 8). Hirsch emplea el término "posmemoria" con el propósito de "expresar su diferencia temporal y cualitativa de la memoria del sobreviviente, su calidad secundaria, de segunda generación, su ubicación en el desplazamiento, en lo tardío". Esta forma mediatizada de la memoria no es menos potente por estar menos unida a la experiencia inmediata. Tiene como resultado una generación que está "forjada por hechos traumáticos que no pueden ni entender ni recrear". La investigación de esta categoría de experiencia en Los rubios representa uno de sus aportes más importantes a la memoria posdictadura en Argentina.

En muchos sentidos, Los rubios es un film que trata de la posibilidad, o la imposibilidad, de hacer un film así en la Argentina contemporánea. De los obstáculos que tuvo que superar Carri para hacer y estrenar la película, el más grave parece ser las negociaciones con el INCAA. Lejos de ser un detalle meramente anecdótico en el camino del guión a la pantalla, este problema llega a ser una parte importante de su investigación acerca de las posibilidades de hacer cine en el contexto argentino. Es más, se hace - literalmente parte de la película, porque la carta que rechaza la solicitud de Carri para el apoyo financiero del INCAA la lee y la discute el equipo de rodaje frente a las cámaras. El escritor de la carta describe el proyecto de Carri como "valioso", pero considera que "pide ser revisado con un mayor rigor documental" para tratar el tema de los padres desaparecidos como se merece. Rigor documental es precisamente lo que falta en Los rubios, pero su cuestionamiento de los procesos de la memoria y de la naturaleza del cine es también lo que hace que la producción sea una intervención tan importante en el cine argentino contemporáneo. Con irreverencia y atrevimiento, Los rubios enfrenta el espinoso tema de la financiación de filmes, la existencia actual de formas insidiosas de censura, y la problemática relación entre el Estado y el cine no industrial.

Por suerte, la decisión inicial del INCAA se revocó, pero el camino de la película por festivales internacionales y hacia la distribución ha sido perseguido por una serie de polémicas. El conflicto entre Carri y los productores, Cine Ojo, fue muy publicitado en la prensa nacional, donde se denunció a Cine Ojo por su actitud excesivamente avara hacia un film que merecía consideración desde otras perspectivas, distintas de la puramente comercial. El debate entró en la esfera pública de una manera contundente el 7 de julio de 2003, cuando Página/12 publicó una lista muy larga de firmantes, que incluía nombres importantes de la cultura, la política, y de organizaciones sociales, que solicitaban una pronta solución al conflicto. 'Los debates publicados reflejan hasta qué punto Los rubios ha logrado abrir un espacio para la crítica, con su insistencia en las relaciones algo menos que transparentes que muchas veces unen los ámbitos políticos, estéticos y comerciales en el proceso de hacer cine. Como nos recuerda Jean-Louis Comolli y Jean Narboni, está fuera del alcance de un solo cineasta, por más revolucionario que sea su enfoque, "efectuar 
un cambio rápido o radical en el sistema económico; deformarlo, sí, desviarlo, pero no negarlo o desbaratar su estructura". Sin embargo, la polémica que ha rodeado la financiación y la distribución de Los rubios ha logrado poner en relieve las tensiones entre intereses artísticos, políticos y comerciales en el cine argentino, y el debate que siguió parece haber aumentado las posibilidades de financiación y distribución, al menos para esta película.

El film de Carri, una historia sumamente personal, difiere de representaciones anteriores de la dictadura debido a su falta de solemnidad, su cuestionamiento de los procesos de la identificación cinematográfica, su autorreflexividad, y su reconocimiento de la complejidad de la memoria y la representación. A la luz de las innovaciones formales de la película y su polémica autoubicación con respecto a la financiación del Estado, el mercado, y la política de la memoria, no parece injustificada la afirmación de Diego Lerer (2003), que "Los rubios amplía el campo discursivo del cine político en la Argentina como ninguna película lo había hecho desde La hora de los hornos". De hecho la película de Carri comparte varias preocupaciones con el cine-ensayo de los sesenta, entre ellas la denuncia a los efectos narcóticos del cine de espectáculo y el intento de convertir al espectador en un participante activo en la creación del sentido. Sin embargo, y a diferencia de los proyectos de los sesenta, el film de Carri no lleva un mensaje ideológico fácilmente identificable; no plantea la identidad como algo recuperable; y no es tan seguro de su capacidad para transformar al espectador en un actor efectivo en la arena política. De una manera más provisoria y más pícara, en Los rubios se combinan lo histórico con lo fantástico, lo traumático con lo totalmente frívolo, con el fin de investigar el dolor de la ausencia y la ausencia del dolor, una de las tantas paradojas que presenta la (no-)experiencia de la posmemoria. El resultado es un cuestionamiento profundo y una revaluación importante de la política de la representación y de hacer cine en la Argentina contemporánea.

Potestad, una película estéticamente muy lejos de la autorreflexividad de Los rubios, también somete a un cuestionamiento radical la memoria y la política del texto cinematográfico. Trata los eventos de la dictadura de una manera única y anómala en el contexto de la memoria posdictadura. En lugar de declararse contra el régimen militar, indaga sobre cómo recordamos, pone al descubierto los mecanismos a menudo insidiosos de la memoria colectiva y revela cómo la memoria se cristaliza en ciertos estereotipos, volviéndose así rígida y opaca. Potestad hace resaltar los procesos de crear sentido en el cine y, lo que es muy significativo, el papel que hace el espectador en estas operaciones. Aunque nos guía al principio hacia una interpretación psicoanalítica de los eventos que narra, el film termina por señalar la insuficiencia de modelos psicoanalíticos que intenten explicar cómo miramos una película. Veremos que estas consideraciones teóricas se muestran plenamente relacionadas con el intento del film de provocar nuevos debates dentro del contexto de la memoria posdictadura.

Potestad es una adaptación libre de una obra de teatro con el mismo título, de Eduardo Pavlovsky, que se estrenó en 1985. En la obra de Pavlovsky, participan sólo dos personajes en un solo escenario, y se trata casi exclusivamente de un monólogo. Dadas estas limitaciones, poco indicadas para el lenguaje cinematográfico, no es de sorprender que llevar la obra a la pantalla fuera un desafío en que trabajaran varios años D'Angiolillo y su coautor, Ariel Roli Sienra. Potestad está construida como un rompecabezas que se arma poco a poco, y en el que la última pieza, ya colocada, cambia de una manera radical nuestra percepción del cuadro. Analizar la película implica, por desgracia, revelar lo que un espectador debería descubrir por sí mismo al verla, y disminuir así el fuerte impacto del film. Por ahora me limitaré a decir que trata sobre el trauma experimentado por Eduardo y su mujer como resultado de la pérdida de su única hija, de diez años, con quien habían disfrutado de una relación íntima y cariñosa. La narrativa parece limitarse a un solo viaje en el subte, que dura tres horas y recorre varias líneas. El laberinto de los túneles y combinaciones es una metáfora visual que refleja la red compleja de digresiones y asociaciones psicológicas del protagonista, cuyo viaje está interrumpido por una serie de flashbacks fragmentados y entrelazados.

D'Angiolillo hace uso de varias técnicas para evocar la desorientación y la paranoia experimentadas por Eduardo. Una de éstas, que agudiza una sensación de lo siniestro en el film, es el uso del primerísimo plano que, según convenciones cinematográficas, tiende a atribuirle un valor simbólico a los objetos. En Potestad estas tomas generan una sensación de inseguridad porque el significado preciso de este simbolismo queda sin aclarar durante la mayor parte de la narrativa. Ritmos insistentes y notas bajas percusivas están intercalados con períodos de silencio para marcar los momentos en que Eduardo pierde o recobra conciencia del presente; los sonidos familiares del subte, como el abrir y cerrar de las puertas y el chirrido del metal contra el metal de las vías, se destacan y se desnaturalizan para crear un efecto siniestro. Se usan secuencias en cámara lenta para desfamiliarizar acciones que no pertenecen al presente narrativo del film y que corresponden a los recuerdos o las proyecciones de Eduardo. El uso del jump cut, cuando Eduardo cae desprevenido en un pozo lleno de huesos humanos, tiene el efecto de fragmentar, literalmente cortar, nuestra percepción de tiempo y espacio, evocando así su terror y incredulidad cuando reconoce lo que está viendo y, desesperado, intenta salir como puede del pozo. Sin embargo, es el montaje - técnica que insinúa conexiones, expone ciertas cosas y oculta otras - que se convierte en la herramienta más importante en la investigación del film sobre la memoria asociativa, su juego de suspenso y revelación, y su cuestiona-miento de cómo se produce el significado en una obra cinematográfica. 
En particular, la experimentación de Potestad con el flashback supone varias desviaciones de las convenciones, todas las cuales anuncian la presencia imborrable del presente en representaciones del pasado. Varios marcos temporales se entrelazan en el film. Algunos de estos hacen referencia a épocas reconocibles, como la guerra de las Malvinas o la Copa Mundial de 1978; otros pertenecen a experiencias particulares del pasado del protagonista o son proyecciones de su deseo o miedo. Las transiciones entre los flashbacks y el presente se inician a menudo con planos de uno de un grupo de objetos cotidianos: un ventilador, la rosa de una ducha, o una calesita de juguete. De esta manera, por ejemplo, la acción traslada desde una toma de Eduardo, que se lava la cara en las duchas del club de rugby, hacia otra ducha, esta vez en el presente y en la casa de Eduardo. El corte es casi invisible, y lo delata sólo el cambio de color de los azulejos en el fondo. El final del primer flashback del film (el principio del cual no se percibe del todo) no está anunciado por ninguno de los medios convencionales - como un fundido acompañado por una voz en off - sino por un cross cutting rápido entre dos perspectivas de Eduardo que está sentado en un tren. En una, reacciona con inquie-tud al grupo que festeja el próximo triunfo sobre los ingleses en las Malvinas; en la otra, está sentado tranquilamente en un vagón casi vacío en el presente del film. Aquí y en otras partes de la película, el entrecruzamiento de secuencias evoca con gran efecto la desorientación psicológica, pero también demuestra la obra asociativa de la memoria, que se niega a obedecer a la organización lineal.

En los flashbacks Eduardo siempre parece tener la misma edad, la del presente. Esta técnica tiene el efecto de ocultar la transición entre flashback y presente, con la consecuencia de que registramos los cambios con incertidumbre. El efecto que se genera es especial-mente anacrónico cuando a Eduardo lo arrastran unos amigos de su juventud para jugar al rugby. Está claro que sus amigos no pueden ver el cuerpo de sesentón que vemos nosotros, y le critican su mal desempeño. Pero si Eduardo mantiene su apariencia presente a lo largo del film, la parte de Ana María la hacen tres actrices distintas, y no se esfuerza el film para hacer que se parezcan versiones más jóvenes o más viejas de la misma mujer. La más joven (Denise Dumas) es rubia y quizás - dada la naturaleza idealizada y fantástica de la escena de las duchas - no representa una persona verdadera sino la proyección del deseo de Eduardo. No se parece ni a la Ana María morocha (Noemí Frenkel) ni a la Ana María mayor y desconsolada (Susy Evans) del presente de la narrativa. La presencia de múltiples Ana María indica hasta qué punto la memoria está contaminada por el deseo. Que el miedo también sea un filtro se hace evidente por el uso de la técnica contraria, en la que distintos personajes los hace un solo actor. La misma moza aparece en dos cafés distintos, y el manifestante de Malvinas en el tren es también el hombre sentado al lado de Eduardo en el presente, e incluso el chofer de Colombres, el socio de Eduardo. La paranoia de
Eduardo se nutre de estas imágenes duplicadas de personajes que, efectivamente, lo acechan a lo largo del film.

Por medio de estas técnicas, Potestad desautoriza el valor de verdad que, según las convenciones del realismo cinematográfico, se le atribuye al flashback como motor de explicación autobiográfica. Además, no es posible ordenar los flashbacks en una secuencia lógica. Cuando Eduardo se despierta en el hospital, mostrando la desorientación que hemos llegado a reconocer como síntoma de su pena al perder a su hija y hablando de la incapacidad de Ana María para superar a la suya, el padrino de Adriana le muestra el collar que acaba de comprar para el cumpleaños de la nena. Más tarde vemos este collar en el cuello de Adriana durante la fiesta de cumpleaños. De esta manera, muchas de las escenas no pertenecen completamente ni al presente ni al pasado.

En Potestad, el uso y la desviación de la convención del flashback son significativos, el primero en su coqueteo con la narrativa explicativa del psicoanálisis, y el segundo, en la desestabilización de ésta. El impacto dramático y político del film proviene principalmente de su explotación de los procesos de la identificación cinematográfica. La adaptación de Murray Smith del concepto psicoanalítico de la identificación es una herramienta útil para explicar cómo el espectador elige tomar partido en Potestad. En la "estructura de simpatías" de Smith, la "alineación" es "el proceso por medio del cual los espectadores están ubicados en relación a los personajes en cuanto al acceso a sus acciones, sus pensamientos y sus sentimientos" (1995:83). En Potestad, el uso frecuente de una voz en off en primera persona, que expresa los sentimientos de desesperación y miedo de Eduardo, establece una relación de confidencialidad y complicidad con el espectador. A veces, su perspectiva se vuelve literalmente la nuestra a través de secuencias filmadas desde su punto de vista. Para Smith, la "alineación" precede a la "afiliación", que representa "la evaluación moral de los personajes por el espectador", una especie de identificación que tiene "dimensiones a la vez cognitivas y afectivas" (84). Aquí nos identificamos plenamente con el protagonista, porque creemos que sabemos cómo terminará la historia y sospechamos que su paranoia está completamente justificada. Su pérdida - dice "me siento fracturado por dentro, dividido en mil pedazos" parece estar vinculada con una experiencia de persecución, a la cual se hace referencia al principio de la película:

Aunque yo sabía que existía la maldad, la imaginaba como una cosa más abstracta, teórica. Pero cuando uno la ve encarnada en personas que se mueven, hablan, gritan, insultan y persiguen a inocentes, la maldad se vuelve más humana, más real, y por eso más temible.

Guiados por imágenes de fosas llenas de huesos humanos, y una calcomanía en el subte con el lema 
"Los argentinos somos derechos y humanos", entre otras referencias a la dictadura, llegamos a estar convencidos de que la desaparición de Adriana tiene algo que ver con los crímenes del régimen militar, o por lo menos que Eduardo puede haber sido una víctima de la represión, aunque no logramos aclarar lo que verdaderamente pasó.

De hecho, esta lectura de los hechos se vuelve cada vez más dificíl de sostener con la paulatina revelación de detalles que parecen contradecirla. Adriana está todavía con Eduardo y con Ana María después del derrocamiento de la dictadura; un viejo conocido acusa a Eduardo de ocultar un secreto vergonzoso; y vemos a Ana María lavar a un bebé por primera vez, que evidentemente no es recién nacido. Muchas de las imágenes recurrentes - el ventilador, la rosa de la ducha, la calesita - pertenecen y presagian una escena de suma importancia que vemos sólo hacia el final de la película. Estas imágenes corresponden al concepto de Freud del recuerdo encubridor: ${ }^{3}$ el recuerdo de detalles triviales que se sustituyen por un recuerdo que es demasiado traumático como para revelarlo. Para Freud, el recuerdo encubridor "debe su valor como recuerdo no a su propio contenido sino a las relaciones que existen entre ese contenido y otro, que ha sido suprimido" (1958a:320). Lo suprimido, en este caso, se revela en un flashback en que Eduardo, como médico que colabora con el régimen militar, descubre a Adriana en el departamento de dos militantes jóvenes recién asesinados por soldados, y la lleva a su casa para criarla como suya.

Reconocemos, demasiado tarde para soltarnos de nuestra compasión por él, que Eduardo, cuando habla del terror de los años setenta, no refiere a las acciones de las fuerzas armadas sino a las de activistas de izquierda. Eduardo intenta inscribirse en el papel del héroe, diciendo: "Eran tiempos de mierda. Una época violenta, irracional. Había que estar allí. Todos los días un enfrentamiento, un ataque por la espalda. Los subversivos habían trastocado todo. No era fácil enfrentar ese odio asesino. Pero hubo que hacerlo". Mientras los cuerpos de los padres de Adriana son arrojados sin ceremonias a un camión, escuchamos las autojustificaciones de Eduardo en una voz en off, que dice: "Fue injusto. Le dimos tanto amor y me la quitaron [...]. Los padres de Adrianita eran fanáticos capaces de volarte la casa. Y yo la salvé". Al saber el verdadero origen de Adriana, podemos reinterpretar la desorientación de Eduardo y comprender que corresponde no sólo a su dolor, sino también a los desplazamientos y las represiones asociados con la culpa.

El tema de la apropiación de bebés por militares durante la dictadura había sido investigado mucho antes en la conocida película La historia oficial (Puenzo, 1985), pero con diferencias importantes. El padre militar en la película de Puenzo es un monstruo, incapaz de sentir compasión, que pega a su mujer y es cómplice en la tortura y la violación de su amiga. La crueldad que muestra Roberto hacia sus padres y su hermano, junto con el beneficio personal que ha obtenido bajo el regimen militar, reafirman nuestro entendimiento de que se trata de un malvado asesino que goza con llevarse por delante a todos los que se interponen en su camino. Como contraste, a Eduardo no lo podemos descartar como monstruo: se parece demasiado a nosotros, y no aceptamos con facilidad que un padre cariñoso y un doctor pueda pertenecer a la misma categoría que un cómplice de asesinatos y un raptor de niños. En el caso de La historia oficial, la información que recibimos acerca de la niñez de Roberto y las relaciones que ha mantenido con su familia nos ayuda a reconstruir la trayectoria de su vida y cómo ha llegado hasta el presente; en Potestad, los flashbacks al pasado ni condenan ni vindican a Eduardo. Dos escenas que podrían servir como justificaciones de su comportamiento de adulto - la tristeza que experimenta la pareja cuando se le da los resultados de la prueba de fertilidad, y la experiencia del rechazo cuando el padre de Eduardo lo reta por no saber qué hacer con su vida sin rumbo - de hecho proveen explicaciones muy inadecuadas. Los flashbacks del film, a pesar de las apariencias, raramente proporcionan datos biográficos de importancia que nos permitieran reconstruir una narrativa coherente de la evolución del personaje de Eduardo.

Sin embargo, muchas convenciones que se emplean en Potestad, como ya hemos visto, nos engañan a los espectadores para que busquemos una interpretación psicoanalítica de los hechos del film. Éstas incluyen, como ya hemos visto, la estructura del flashback, la desorientación del protagonista, la problemática relación con el padre, el predominio de la voz en off en primera persona, y temas de la pérdida, la paranoia y - más tarde - la culpa.

Entendemos muy pronto que los flashbacks representan elementos reprimidos que persiguen al protagonista y, por lo tanto, asumimos el rol del analista, interpretando una serie de asociaciones para descubrir lo que trata de recordar el paciente. Además, el comportamiento de Eduardo parece seguir la descripción de Freud de la elaboración como una repetición compulsiva que reemplaza la memoria (1958b:150). La desaparición de Adriana, por ejemplo, está representada tres veces, todas de manera distinta, dentro de la narrativa del film. Otra sublimación se deja ver en una de las escenas más surrealistas del film, en que Eduardo no logra salvar a un paciente al que está operando de una herida de bala. El paciente sufre una hemorragia y se muere a causa de la negligencia del médico. Que esta escena se pueda interpretar como otro desplazamiento, otra repetición compulsiva de la culpa y la complicidad, queda de manifiesto cuando llegamos al departamento de los padres de Adriana. Dos repeticiones conectan estas dos escenas: primero, el brazo flácido del paciente que cuelga de la mesa de operaciones, a lo largo del cual corre un hilo de sangre, se transforma en el brazo de la madre de Adriana, tumbada muerta en la cama; segundo, en el quirófano a Eduardo le dicen, de una manera insinuante, "¿En qué mejores manos podría estar, no, doctor?", que es precisamente la frase que 
emplea Colombres cuando descubren a Adriana en el baño del departamento. Sostengo, sin embargo, que el énfasis del film sobre lo psicoanalítico es una parte fundamental de su decepción del espectador, y que la verdadera función de lo psicoanalítico en este film es para poner en relieve lo político.

Algo de la importancia de las operaciones retóricas del film y su relación con lo político se capta si se compara Potestad con ese clásico del expresionismo alemán, El gabinete del Doctor Caligari (Robert Wiene, 1920). Las dos películas contienen flashbacks que resultan ser engañosos; ambas toman como tema el abuso de la autoridad y el desorden psíquico; se centran en un médico que es cómplice en múltiples asesinatos; intentan subvertir la linearidad narrativa por medio de la repetición, la sublimación, la elipsis y la redundancia. Sin embargo, desde la publicación en 1947 del trabajo de Siegfried Kracauer, Von Caligari zu Hitler: Eine psychologische Geschichte des deutschen Films (De Caligari a Hitler: Una historia psicológica del cine alemán), muchos críticos han coincidido en que el marco narrativo del film de Wiene efectivamente neutraliza el significado político de la película, puesto que desacredita la versión que se nos ofrece de la culpabilidad del doctor: al final del film, entendemos que el narrador es un paciente psiquiátrico con delirios paranoicos que se centran en el director del manicomio. La presencia del marco narrativo da crédito a una lectura psicoanalítica en lugar de una lectura política, y atenúa la crítica del film que, según Kracauer, sin este elemento habría ofrecido una visión atrevida de la locura institucionalizada de la vida pública de Alemania entre las guerras. En Potestad, se deja ver el revés de este proceso narrativo. Si el film de Wiene empieza con los crímenes, y luego sugiere que su autor es el médico, el de D'Angiolillo nos presenta primero al médico y después sus crímenes, que permanecen ocultos en la sociedad debido a la garantía de impecabilidad moral que posee: su bata blanca. Al final de Caligari, el orden se restablece (después de todo, el médico no es culpable); en Potestad, el final pone al descubierto nuevos abismos insalvables en la sociedad que representa. Las simetrías de Potestad nos obliga a reconocer la insuficiencia de interpretaciones psicoanalíticas para explicar la diferencia ideológica: en este film es lo político que surge como un resto persistente que no se puede simplificar o reducir a la psicología.

De manera ofensiva, la película parece sugerir que la memoria posdictadura funciona, hasta cierto punto por lo menos, como un recuerdo encubridor, y que lo suprimido es la violencia de los militantes de izquierda de los años setenta. Es necesario reconocer que el film no justifica, de ninguna manera, la violencia ejercida por el régimen militar; tampoco intenta reducir la enormidad de sus crímenes. Pero nos obliga a ver las simetrías de la violencia a ambos extremos del espectro político. ¿Qué pasa cuando los raptores de niños hablan nuestro mismo lenguaje? ¿Hasta qué punto el quitarle a Adriana a sus autoproclamados padres, que la quieren muchísimo, realmente ayuda a reintegrar una sociedad destruida? Como dice Eduardo, Adriana ha sufrido dos veces, al perder dos veces los padres. Si ambos lados del conflicto participan en la violencia, y si ambos lo hacen con el fin de crear un mundo mejor para sus hijos, la ecuación parece cerrar, por lo menos momentánea y precariamente. Al final de la película quedamos con la cuestión - muchas veces dejada de lado por la memoria posdictadura - de cómo negociar una existencia compartida con el Otro, cuyas convicciones ideológicas no son las nuestras. Es también la cuestión de cómo recordar sin reinventar las mismas estructuras de alteridad que produjeron las condiciones del evento traumático original. En Potestad, el espectador se vuelve cómplice en los procesos de alteridad y prejuicio, por medio de los cuales incluso las contramemorias pueden adoptar el discurso monológico del autoritarismo. Con inquietud, comprendemos que nuestra disposición para demonizar al enemigo nos ha metido en el campamento equivocado. Esta comprensión nos permite percibir los mecanismos insidiosos y maniqueístas que subyacen a todo tipo de memoria, y entender que la realidad histórica es siempre más rica y más compleja que lo que nos deja vislumbrar su destilación en la memoria.

Que la memoria posdictadura no se haya enfrentado por completo a estas cuestiones ha sido señalado recientemente por varios críticos y teóricos argentinos. Beatriz Sarlo (2002:45-46) argumenta que "Todavía falta colocar a la dictadura militar en la perspectiva de los años que la precedieron. La dictadura fue excepcional en un sentido, el de su extremismo. Pero, en otro sentido, es un capítulo que se abre en los años setenta, antes del golpe militar. Precisamente será necesario reinterpretar los hechos e ideas hegemónicas de las últimas décadas". Héctor Schmucler (2000:9) nos hace acordar de la violencia y las divisiones que caracterizaban la sociedad argentina antes del golpe, y sostiene que "Deberíamos arriesgarnos a reconocer las condiciones que propiciaron el golpe de estado de 1976 y a registrar que fue bienvenido por gran parte de la población"; de modo parecido Hugo Vezzetti afirma que, mientras la brutalidad de la dictadura fue sin precedentes en la historia argentina, y por eso representa hasta cierto punto lo que llama "una irrupción", fue también "un desenlace, a partir de una larga crisis política, incluso de una guerra civil larvada" (2001:12). Vezzetti hace un llamado a construir "una memoria de las memorias", a analizar de qué maneras los mecanismos narrativos de la memoria estilizan y simplifican representaciones del pasado. Al reflexionar sobre el aniversario de 25 años desde el golpe, asegura que el debate público en Argentina acerca de ese período de su historia sigue siendo "sumamente limitado y casi estereotipado" (13). Potestad, escandalosamente imparcial en su trato de la violencia de los militares y de los disidentes, constituye un intento serio de reabrir espacio para el debate público, de problematizar las represen-taciones estereotipadas del pasado, y de ubicar los crímenes de la dictadura en el contexto de los conflictos ideológicos de los años setenta. El 
mismo Pavlovsky implica ambos lados del conflicto en su crítica de la violencia ideológica, resumida en el Prólogo a la obra Potestad: "Se acabó la época de los matones a sueldo, de los grandes psicópatas de la tortura; llegó la época de los ideólogos, de los filósofos de la libertad. Una nueva religión aparece y nace, entonces, una nueva patología social" (2001:13). El Potestad de D'Angiolillo intenta así un revisionismo de un revisionismo anterior, obedeciendo un impulso muy del siglo veintiuno a denunciar el extremismo ideológico en todas sus manifestaciones.

Quizás con mayor importancia, Potestad nos conduce a reconocer que la memoria de un país dividido no puede ser sino un espacio de conflicto. Discusiones recientes han pedido una nueva heterogeneidad y mayor sutileza en la memoria posdictadura; este mayor entendimiento de la importancia de la diferencia debería compensar la obligación a reconstruir la unidad nacional por medio de la memoria colectiva. La memoria colectiva es, como nos recuerda Schmucler, fundamental a la nación como concepto; sigue siendo una tarea difícil en Argentina, que tiene que aceptar que "pueden reconocerse diversas memorias" y que "el "clima de la época" pesa de manera distinta en cada una de ellos" (2000:8). Según Oscar Terán, no se debería "embalsamar los hechos del pasado para construir un panteón reconciliado" (2000:11). La reconstrucción de la memoria colectiva no debe efectuarse a cualquier precio, y menos aún si corremos el peligro de olvidar o disimular las diferencias y las divisiones que han caracterizado la sociedad argentina desde mucho antes del golpe.

En el revisionismo que sugiere el film de D'Angiolillo, el rol del espectador es clave. Al igual que Potestad presenta un marco analítico - el psicoanálisis - sólo para desestabilizarlo, un examen de cómo el film sitúa al espectador (o como éste se sitúa con relación al film) nos conduce lejos de modelos psicoanalíticos de la mirada del espectador. Si la teoría psicoanalítica del cine ubica al espectador en el rol de un analista que interpreta el texto-sueño de la película, Potestad nos obliga a enfrentar nuestra incompetencia como analistas y a reconocer nuestros prejuicios. La ilusión de dominio sobre el mundo que, según esta teoría, nos provee la perspectiva omnisciente y omnividente del cine, se encuentra aquí totalmente destruida: nuestra percepción de los eventos del film, y de los hechos reales en los cuales está basado, está completamente debilitada.

En Potestad el espectador no es el objeto pasivo de la interpelación o la sutura como lo entendieran Lacan y Althusser. Al contrario, es un participante activo que ayuda a construir el texto, guiado en este acto de interpretación, no por procesos inconscientes, sino por su conocimiento fuera de film y su expe-riencia. Potestad nos recuerda que los sentidos se producen por medio de relaciones complejas entre espectador, film, y contexto sociocultural. David Bordwell avanza un modelo opuesto al psicoanálisis, el del cognitivismo, para entender la relación entre espectador y film. Si - como sostiene él - los espectadores abordan la tarea de hacer hipótesis con "esquematas" interpretativas ya establecidas, la relación del espectador con el film implica una serie de mecanismos que no son inconscientes, sino preconscientes. Esta distinción supone una gran diferencia en términos políticos. Si la ideología y la memoria pertenecen a esferas preconscientes, existe la posibilidad de que éstas puedan abrirse como espacios de conflicto, resistencia y negociación. Ésta es la consecuencia política de la teorías mucho más flexibles de la relación entre película y espectador que surgen del cognitivismo y los estudios culturales, que suponen un mayor grado de intercambio entre la subjetividad y la representación cultural. Como opina Bordwell, la teoría psicoanalítica del cine no provee "una explicación satisfactoria de cómo actores sociales podrían criticar o resistir la ideología", ya que "no hay espacio para el "protagonismo" en un marco en que la subjetividad esté determinada con tanta rigurosidad por las representaciones ideológicas" (1996:8). A la investigación algo universalista de los cognivitistas del proceso de construir historias, Robert Stam querría agregar "la noción de una posición, un mirador que está determinado por lo social, de lo que invierten los espectadores en la representación, nociones de cuadriculados ideológicos y narcisismos culturales que reflejan el encauzamiento social de la entrada emocional" (2000:245). De esta manera, Potestad insiste en que la mirada del espectador esté históricamente, culturalmente y socialmente condicionada, y pone en relieve la importancia de la ubicación en la construcción de significados en el cine. Logra ubicar al que Stephen Prince (1996:73) Ilamaría el espectador "desaparecido" de la teoría psicoanalítica del cine, al igual que el espectador abstracto, sin posición, de la teoría cognitivista.

El poder de Potestad es transformarnos, como espectadores, en el objeto de nuestra propia mirada hasta tal punto que reconozcamos nuestra incapacidad para leer correctamente el film, no como un defecto intelectual, sino como un error de memoria. Igual que todas las representaciones, la memoria traiciona a su objeto: borra la realidad al mismo tiempo que la preserva. Las condensaciones, asociaciones y desplazamientos de la memoria se reflejan en la construcción y la interpretación de películas. En última instancia, parece que queremos que la memoria nos den el mismo placer narrativo que nos da el cine: hacer heroicos a nuestros héroes, y a nuestros villanos la encarnación de la pura maldad; establecer relaciones claras de causalidad y atar todos los cabos sueltos. En oposición a estas falsificaciones, Potestad se revela como un film verdaderamente contracultural, y de esta manera se une a los que reconocen la dificultad de recordar de otro modo, y que comienzan a pedir más heterogeneidad, más divergencia y más conflicto dentro de la memoria posdictadura. 


\section{Notas}

Desde aquí y en adelante las traducciones del inglés al castellano son de la autora.

${ }^{2}$ Véanse, por ejemplo, los artículos escritos por el sociólogo Horacio González ("Imperativos de la conciencia") y la científica social Alcira Argumedo ("Un gran triunfo sobre el horror") en Página/12: Espectáculos, 12 de julio de 2003. González asegura que "El lenguaje [comercial] que emplea Céspedes no es apropriado para tratar este tema. [...] Sería bueno que perciba la verdadera dimensión de este conflicto". A la descripción del conflicto dada por Marcelo Céspedes de Cine Ojo como "estrictamente comercial", Argumedo afirma que "Es evidente que el productor no entendió en absoluto el denso significado de la película que durante dos años ayudó a producir".

"En inglés se traduce como "screen memory", una frase evocadora que Ilama la atención al doble significado de la palabra "screen": primero, como algo que oculta o tapa, y segundo como pantalla o la acción de proyectar una película.

\section{Bibliografía}

Bernades, H. (2003), "Los desaparecidos, una investigación familiar", Página/12: Espectáculos, 24/ 04/2003, http://www. pagina12 web.com.ar/diario/ espectaculos/6-19225-2003-4-24.html.

Bordwell, D. (1985), Narration in the Fiction Film, London: Methuen.

. (1996), "Contemporary Film Studies and the Vicissitudes of Grand Theory", Post-Theory: Reconstructing Film Studies (ed. D. Bordwell y N. Carroll), Madison: University of Wisconsin Press, pp. 3-36.

Bruzzi, S. (2000), New Documentary: A Critical Introduction, London and New York: Routledge.

Comolli, J.-L. and Narboni, J. (1999), "Cinema/ldeology/Criticism", Film Theory and Criticism: Introductory Readings (ed. L. Brandy y M. Cohen), Oxford: Oxford University Press, pp. 752-59.

Freud, S. (1958a), "Screen Memories", The Standard Edition of the Complete Psychological Works of Sigmund Freud (trad. J. Strachey), London: Hogarth Press, vol. 3, pp. 303-22.

(1958b), "Remembering, Repeating and Working-Through", The Standard Edition of the Complete Psychological Works of Sigmund Freud (trad. J. Strachey), London: Hogarth Press, vol. 12, pp. 14756.

García, E. (2003), " "Barbie y el "Cuchu", dos nuevas estrellas en el cine de animación", Página/12: Espectáculos, 13/08/2004.

http://www.pagina12web.com.ar/diario/espectaculos/ 6-24038-2003-8-13.html.

García, F. (2003), "Un nombre marcado a fuego", Clarín: Sociedad, 9/11/2003, http://old.clarin.com/ diario/2003/11/09/s-04602.htm.

García, L. (2003), "Albertina Carri: "La ausencia es un agujero negro"", La Nación: Espectáculos, 23/04/ 2003, http://www.lanacion.com.ar.

Hirsch, M. (1999), "Projected Memory: Holocaust Pho- tographs in Personal and Public Fantasy", Acts of Memory: Cultural Recall in the Past (ed. M. Bal, J. Crewe y L. Spitzer), Hanover: University Press of New England, pp. 3-23.

Kracauer, S. (1947), From Caligari to Hitler: A Psychological History of the German Film, London: Dobson. LaCapra, D. (1998), History and Memory After Auschwitz, Ithaca and London: Cornell University Press. Lerer, D. (2003), "La fábula de la reconstrucción", Clarín: Espectáculos, 23/10/2003,

http://old.clarin.com/diario/2003/10/23/c-00909.htm. Moreno, M. (2003), "Esa rubia debilidad", Página/ 12: Radar, 23/10/2003,

http://www.pagina12web.com.ar/suplementos/radar/ vernota.php?id_nota $=1001$.

Nichols, B. (1991), Representing Reality: Issues and Concepts in Documentary, Bloomington and Indianapolis: Indiana University Press.

Pavlovsky, E. (2001), Prólogo, Potestad, Buenos Aires: Galerna, pp. 13-17.

Prince, S. (1996), "Psychoanalytic Film Theory and the Problem of the Missing Spectator", Post-Theory: Reconstructing Film Studies (ed. D. Bordwell y N. Carroll), Madison: University of Wisconsin Press, pp. 71-86. Sarlo, B. (2002), Tiempo presente: notas sobre el cambio de una cultura, Buenos Aires: Siglo XXI.

Schmucler, H. (2000), "Las exigencias de la memoria", Punto de vista, 23: 68, pp. 5-9.

Smith, M. (1995), Engaging Characters: Fiction, Emotion, and the Cinema, Oxford: Clarendon Press. Stam, R. (2000), Film Theory: An Introduction, Oxford: Blackwell.

Sturken, M. (1997), Tangled Memories: The Vietnam War, the AIDS Epidemic, and the Politics of Remembering, Berkeley: University of California Press.

Terán, O. (2000), "Tiempos de memoria", Punto de vista, 23: 68, pp. 10-12.

Tirri, N. (2002), "Pavlovsky, del teatro al cine", La Nación: Espectáculos, 18/01/2002, p. 4.

Turim, M. (1989), Flashbacks in Film: Memory and History, New York and London: Routledge.

Vezzetti, H. (2001), "Lecciones de la memoria: a los 25 años de la implantación del terrorismo de estado", Punto de vista, 24: 70, pp. 12-18. 